\title{
A reconfiguração da cultura docente na revista argentina La Obra (1970-1980)
}

\author{
Educator culture reconfigured in the \\ argentinean publication La Obra (1970-1980) \\ La reconfiguración de la cultura docente en la \\ revista argentina La Obra (1970-1980) \\ Daniel Revah \\ Universidade Federal de São Paulo (Brasil) \\ https://orcid.org/0000-0002-1560-2691 \\ http://lattes.cnpq.br/7146201520291194 \\ revah@uol.com.br
}

\section{RESUMO}

Este artigo destaca determinadas representações sobre a docência presentes na revista $L a$ Obra com a intenção de pôr em foco alguns aspectos da reconfiguração da cultura docente que se opera, na Argentina, nas décadas de 1970 e 1980. Discutem-se certos sentidos e significados implicados nessa reconfiguração a partir do que pode ser observado nessa revista, principalmente em seus editoriais e artigos. As representações analisadas concernem ao viés tecnocrático da Reforma Educativa iniciada na Argentina no final dos anos 1960, à desvalorização dos docentes e suas lutas sindicais, às restrições impostas ao magistério no período da última ditadura, à valorização da dimensão política da docência na transição democrática e, nos anos 1980, à emergência do construtivismo como discurso pedagógico.

Palavras-chave: Cultura Docente. Periódico Educacional. Argentina. 


\begin{abstract}
This article point out certain representations about the teaching on La Obra journal, focused on a few aspects of the teaching culture reconfiguration in Argentina, between 1970s and 1980s decades. Certain meanings involved in this reconfiguration are discussed from what can be seen in this journal, especially in its editorials and articles. The representations analyzed concern the technocratic bias of the Educational Reform initiated in Argentina in the late 1960s, the devaluation of teachers and their union struggles, the restrictions imposed on teachers during the last dictatorship, the valorization of the political dimension of teaching in the democratic transition, and in the 1980s, to the emergence of constructivism as a pedagogical discourse.
\end{abstract}

Key words: Educator culture. Educational publication. Argentina.

\title{
RESUMEN
}

Este artículo destaca determinadas representaciones sobre la docencia presentes en la revista La Obra con la intención de enfocar algunos aspectos de la reconfiguración de la cultura docente que se opera, en la Argentina, en las décadas de 1970 y 1980. Se discuten ciertos sentidos y significados implicados en esa reconfiguración a partir de lo que se observa en dicha revista, principalmente en sus editoriales y artículos. Las representaciones analizadas conciernen al sesgo tecnocrático de la Reforma Educativa iniciada hacia fines de la década de 1960, a la desvalorización de los docentes y sus luchas gremiales, a las restricciones impuestas al magisterio en la última dictadura, a la valorización de la dimensión política de la docencia durante la transición democrática y, en los años 1980, a la emergencia del constructivismo como discurso pedagógico.

Palabras clave: Cultura docente. Revista educacional. Argentina. 


\section{Introdução}

$\mathrm{Na}$ segunda metade do século passado ocorreram importantes transformações na cultura docente e os periódicos educacionais dirigidos aos professores, além de acompanhar quase que passo a passo essas e outras mudanças em seus diferentes matizes e tensões, com as representações e conflitos que emergiram em cada momento, participaram ativamente nesse processo. ${ }^{1}$ Este trabalho põe em foco essas transformações nas décadas de 1970 e 1980 e toma a revista educacional La Obra como um objeto cultural que incide na reconfiguração da cultura docente que se opera na Argentina nesse período. O objetivo deste artigo é discutir certos sentidos e significados implicados nessa reconfiguração a partir do que pode ser observado nessa revista, sobretudo em seus editoriais e artigos. ${ }^{2}$

Quando aqui se fala em cultura docente, faz-se referência na verdade a um universo heterogêneo, tensionado e conflitivo que a rigor exigiria falar no plural, em culturas docentes. No caso específico da revista argentina La Obra, a referência à cultura docente concerne às representações que a própria revista (re)produz e veicula sobre os docentes e a docência, de modo que discutir a sua reconfiguração é primeiramente analisar as mudanças que ocorreram no interior dessa publicação. Sob essa perspectiva, buscou-se atentar para as inflexões que podem ser observadas nos discursos sobre os docentes, os remanejamentos e continuidades, as tensões e conflitos que a revista expõe ou aos quais alude nas entrelinhas, por vezes vinculando-os - explícita ou implicitamente - a determinadas questões em pauta no contexto histórico em que surgem.

Em relação à importância e ao lugar da revista La Obra entre os docentes argentinos, cabe destacar que essa publicação conservou ao longo de décadas uma significativa acolhida, com elementos da sua fórmula editorial que foram mantidos ou que pouco variaram, afora outros que foram significativamente alterados. ${ }^{3}$ A própria origem da revista concerne aos docentes, pois foi lançada em 1921 por um grupo de "maestros"4 partidários do escolanovismo, convertendo-se depois em um periódico de uma empresa editorial cuja publicação foi mantida de forma quase que ininterrupta até o final do século passado, prosseguindo inclusive posteriormente (FINOCCHIO, 2009, p. 92-3). ${ }^{5}$ Destinado basicamente aos docentes e com artigos escritos sobretudo por eles, ao longo do século XX teve seu foco voltado para os níveis iniciais do ensino, com propostas concretas de trabalho para desenvolver na sala de aula e tendo como preocupação a renovação dos métodos e propostas de ensino (idem, p. 92 e 155).

Esse leitor visado pela revista La Obra constitui um elemento fundamental para avaliar o sentido das opções editoriais e as representações nela veiculadas sobre a docência, em particular se considerarmos as históricas diferenças entre as culturas docentes dos vários níveis do ensino (pré-escolar, primário e secundário), sem contar a conformação majoritariamente feminina de seus leitores, dada a composição do magistério quanto ao gênero predominante nos níveis iniciais. Em relação a esses primeiros níveis, considerou-se ainda o percurso específico

\footnotetext{
1 O papel da imprensa educacional na configuração do campo pedagogico já foi ressaltado por vários pesquisadores, como Carvalho (2006), Nóvoa (1997) e Finocchio (2009).

${ }^{2}$ A pesquisa que deu origem a este trabalho foi desenvolvida no pós-doutorado realizado pelo autor em 2015 na Facultad Latinoamericana de Ciencias Sociales (FLACSO), na sua sede em Buenos Aires, e contou com o financiamento da FAPESP.

3 Jorge Fasce, Chefe de Redação entre 1978 e 1983, afirma que a revista La Obra vendia trinta mil exemplares em 1983, em entrevista dada em 2010 à Andrade (2016, p. 29).

${ }^{4}$ A denominação "maestro" corresponde na Argentina ao docente do ensino primário.

${ }^{5}$ Somente deixou de ser editada em 1977, por razões econômicas, segundo Andrade (2016, p. 28).
} 
da cultura docente nessa revista tendo em vista a forte corrosão do normalismo que ocorreu no período aqui em questão e o modo como ela se posiciona a esse respeito. ${ }^{6}$

Ainda em relação à cultura docente compreendida como um campo heterogêneo, conflitivo e no qual estão em disputa diversas representações sobre os docentes e a docência, são também destacadas algumas representações que circularam em outros impressos educacionais, pois possibilitam situar melhor o que estava em jogo em determinadas circunstâncias históricas e qual a posição da revista La Obra nessas lutas de representação. ${ }^{7}$ É o que será feito a seguir, dando destaque a certas representações que circularam na imprensa educacional oficial no final dos anos 1960, durante a ditadura da autodenominada "Revolución Argentina".

\section{"Modernização" educativa, desvalorização do professor e luta sindical}

$\mathrm{Na}$ Argentina, desde meados do século XX, "los hilos del cambio educativo se entretejieron con los de 'la crisis educativa", conforme lembra Finocchio (2009, p. 133), que também aponta que "el discurso del cambio estuvo liderado por la prensa oficial". Isso é particularmente expresso no nome da revista oficial Educación y Cambio, lançada pelo Conselho Nacional de Educação em 1970, em substituição à revista El Monitor de la Educación Común. Em suas páginas, o que basicamente está em pauta é a Reforma Educativa que o Ministério de Cultura e Educação busca implementar nesse período com a participação dos setores privatistas que vinham ganhando terreno no ámbito do Estado desde fins dos anos 1950, os quais continuavam bem presentes nesse momento, no fim do governo ditatorial do general Onganía (PUIGGRÓS, 2003; PINEAU, 2006). Nessa reforma, que pretende mudar a estrutura do sistema educativo promovendo alterações curriculares e reorganizando o sistema com a criação de um novo nível ("escuela intermedia"), os docentes são colocados no centro da cena. Eles são vistos pelas autoridades como os principais protagonistas do "cambio educativo" e por isso são alvo de uma forte investida por parte dos discursos oficiais, especialmente os docentes da escola pública. Eles são incitados a modernizar a escola, os métodos e as práticas pedagógicas. A escola está em crise e sair dela exige modernizar-se: "La modernización es exigencia, no opción", diz Gelderen, um dos arautos da reforma que escreve em Educación y Cambio. ${ }^{8}$ Para implementar a reforma e assim modernizar o sistema educativo, a escola e os docentes, promovem-se várias iniciativas e são mobilizados especialistas com um discurso tecnocrático que encontra forte resistência entre os docentes, incentivados a participar mas ao mesmo tempo limitados em seus direitos políticos. Entre as iniciativas então implementadas, além da própria revista Educación y Cambio, estão os cursos de "adiestramiento", nos quais os docentes podem se apropriar da parafernália técnica e didática em voga nesse momento, como a instrução programada e a educação personalizada. Com concepções que evidenciam o viés comportamentalista de muitas proposições pedagógicas, a formação docente parece ficar no mesmo registro, sendo a esse respeito sintomático o uso do significante "adiestramiento", conforme pode ser observado nas páginas da revista Educación y Cambio. ${ }^{9}$

A representação dos docentes que essa revista oficial divulga em suas páginas nesse período os coloca como fundamentais para a efetivação da Reforma Educativa e, em

\footnotetext{
${ }^{6}$ Southwell (2003, p. 119) afirma que nos anos 1970 o normalismo ainda era hegemônico, mas estava desgastado.

${ }^{7}$ As lutas de representação são aqui concebidas de uma maneira semelhante à que propõe Roger Chartier (1991), como lutas que envolvem representações coletivas e nas quais os periódicos educacionais, como a revista aqui analisada, adotam diferentes posições, incidindo assim nessas lutas e nos grupos que pretendem representar.

8 Cf. Alfredo Manuel van Gelderen, no artigo intitulado "Análisis del Programa Educativo", Educación y Cambio $\mathrm{n}^{\mathrm{o}}$ 1, p. 11. Na frase de Gelderen temos o que Miriam Southwell (2003, p. 107) destaca como "central para la época: la modernización. Esta constituyó el lugar de llegada de una multiplicidad de enunciados pedagógicos".

9 Cf. "Cursos de Adiestramiento", Educación y Cambio n ${ }^{\circ}$ 5, p. 6-8. Sobre a presença da psicologia comportamentalista na Argentina nesse período, veja-se Southwell (2003) e Pineau (2006).
} 
consequência, para o desenvolvimento do país. Por vezes os elogia, mas também os critica, apontando por exemplo sua complicidade com "tabúes escolares" que devem ser desterrados e seu apego a normas cujo fundamento fazia sentido no passado e que no momento atual seriam a expressão mais acabada da rotina; numa escola onde primaria "el envejecimiento y la desactualización de objetivos, contenidos e instrumentos escolares", em um sistema educativo excessivamente burocratizado e centralizado e "que por su estatismo y obsolencia (sic) parece querer frenar más que impulsar la acelerada transformación que se da en todo el mundo", conforme afirma o editorial do segundo número da revista, intitulado "Los maestros ante el cambio". ${ }^{10}$ Alude-se nesses discursos oficiais à resistência docente com explicações diversas. Gelderen, por exemplo, inicialmente atribui as reações contrárias a posições afetivas ou sentimentais por parte de docentes cujas posições político-escolares não se assentariam em nenhuma filosofia e tampouco teriam fundamento técnico-científico. Mas também se refere posteriormente a questões ideológicas, num período em que esse tipo de questões vêm à tona com força e que corresponde ao surgimento de novas entidades de classe dos docentes. ${ }^{11}$

Os "modernos" enfoques que os discursos oficiais incitam a adotar vinham sendo divulgados desde os anos 60, embora não necessariamente no âmbito desses discursos, pois houve diferentes e às vezes contrastantes posições ideológicas nas várias gestões que se sucederam nesses anos na pasta de Educação. ${ }^{12} \mathrm{Na}$ revista La Obra nota-se também a presença desses novos enfoques ou tecnologias do ensino desde a década de 1960, como pode ser observado na sua edição de setembro de 1967, na seção "Temas de actualidad pedagógica", onde se fala sobre a instrução programada e as máquinas de ensinar $\left(n^{\circ} 638\right.$, p. 395). Essa publicação adota uma posição de defesa e também crítica em relação à Reforma Educativa, por vezes inclusive de maneira bem ácida e irônica, como nos editoriais das edições de setembro, outubro e novembro de 1971. Nesses editoriais, a reforma é atribuída a especialistas cujas "lucubraciones" na sua maior parte "no son otra cosa que fantasías trasnochadas", "reformas de laboratorio" feitas num período em que muitos sofrem de "objetivitis" - "la manía de los objetivos" - e utilizam "un lenguaje retorcido o pomposamente técnico". ${ }^{13}$

Os editoriais da revista La Obra desse período por vezes dirigem-se a seus leitores chamando-os de colegas, assim construindo uma representação dos docentes que corresponde a seus próprios posicionamentos. No caso da Reforma Educativa e do discurso e práticas tecnicistas que a reforma promove, sobressai seu posicionamento crítico, adotado também em relação a outras políticas governamentais que são objeto de comentários em seus editoriais, por vezes inclusive envolvendo o questionamento de aspectos ou dimensões do sistema educativo como um todo que não concernem necessariamente à pauta daquela reforma. Nesses editoriais, alude-se entre outros assuntos aos baixos salários, às reformas que não dão certo e à não aplicação do Estatuto do Docente. Muitas das questões que a revista levanta referem-se às condições de trabalho dos docentes, mas também há questões propriamente pedagógicas, relativas aos novos currículos, e ainda sobre a deserção escolar, a repetência, a precariedade material de muitas escolas e a desigualdade. Esta última uma questão que em editoriais se traduz na ideia da existência de duas Argentinas: uma delas vive ou quer viver no século XX, enquanto a outra, a cinderela da vida nacional, continua sepultada, vegetando

\footnotetext{
${ }^{10}$ Cf. Educación y Cambio, no 2, p. 1.

${ }^{11}$ Cf. Alfredo Manuel van Gelderen, nos artigos intitulados “Análisis del Programa Educativo", Educación y Cambio $\mathrm{n}^{\mathrm{o}} 1 \mathrm{e}^{\mathrm{o}} 2$.

${ }^{12}$ Em 1969, por exemplo, no momento em que é lançada a única edição desse ano da revista oficial El Monitor de la Educación Común, a pasta de Educação estava a cargo de José Mariano Astigueta, que pertencia ao grupo de intelectuais católicos mais conservadores (PUIGGRÓS, 2003, p. 54) cujas posições refletem-se nessa edição da publicação oficial. Esse grupo era avesso à perspectiva tecnocrática e modernizadora que se afirma logo depois.

13 A Reforma Educativa gerou muitos questionamentos entre 1970 e 1971, "hasta que finalmente fue suspendida su aplicación", como lembra Southwell (2003, p. 118).
} 
"porque arrastra una condena sin remedio", uma Argentina cujos "desgarrados gritos (...) pidem participación, vida propia, integración niveladora". ${ }^{14}$

Essa representação dos docentes como críticos das políticas governamentais, que anseiam também pelo retorno da ordem constitucional, conflui e se funde à do docente que luta por seus direitos e que participa no seu sindicato - um tema que percorre as páginas da revista nos anos 1960, intensificando-se na primeira metade da década seguinte.

O posicionamento crítico da revista acentua-se nos primeiros anos da década de 1970, em consonância com as mobilizações sociais que cresceram nesse período e cuja expressão mais significativa foi "el Cordobazo", quando trabalhadores e estudantes tomaram as ruas da cidade de Córdoba em 1969, desestabilizando desse modo a ditadura de Onganía e obrigandoo a deixar o poder no ano seguinte, quando foi substituído pelo general Levingston. Nesses anos, a revista La Obra constata em vários editoriais a perda de prestígio do magistério, a desvalorização da docência como atividade profissional, lembrando por exemplo que houve "una época feliz, hace ya muchos años, en la cual el maestro argentino tenía en la sociedad una posición - un status, diríamos hoy - francamente privilegiada" (abr. 1971, n 668, p.1). Referindo-se a esse "sufrido gremio", os editoriais assumem uma posição de defesa dos docentes e criticam a desvalorização de que são objeto, em discursos que questionam por exemplo a preparação dos "maestros" - que em sua grande maioria são na verdade "maestras" - porque formados no normalismo, nessa cultura sedimentada nas escolas normais que vai sendo crescentemente corroída nessas décadas, pelos discursos oficiais, mas também desde outros âmbitos e em parte pela própria revista. ${ }^{15}$ Nela reconhece-se que a escola normal não preparava "los mejores maestros posibles. Sería francamente exagerado" (ago. 1971, n 672, p. 362). Ao mesmo tempo, porém, ressaltam-se determinadas dimensões em sua defesa e expressa-se a preocupação pelo seu destino, levando em consideração o que as escolas normais até então representavam na formação dos docentes e a sua extinção quando essa formação foi elevada do nível secundário para o nível superior, entre 1967 e 1970 (SOUTHWELL, 2003, p. 114). Diante do discurso que desvaloriza os docentes pela sua formação e atuação, a posição da revista por vezes é de exaltação do magistério, como consta no editorial de junho de 1973: "el magisterio argentino tiene, en su conjunto, una calidad profesional que lo pone a la altura de los mejores del mundo" ( $\left.\mathrm{n}^{\circ} 688, \mathrm{p} .218\right)$.

Nesse ano, os civis assumem novamente o governo, após quase sete anos de vigência do regime militar instituído pela chamada "Revolución Argentina". Inicia-se assim o breve período democrático que se estende até março de 1976. Nesse momento, naquele mesmo editorial, afirma-se que "la educación no debe ser un privilegio" e é feita esta avaliação sobre o que vinha ocorrendo com a escola e os docentes: "Nadie duda de que la escuela argentina ha sufrido mucho, y que también los docentes han penado largamente" (jun. 1973, n ${ }^{\circ}$ 688, p. 217-8). Ademais, em sintonia com a intensa mobilização social e política desse período, reafirma-se a figura do docente que se mobiliza e levanta sua voz:

Los docentes, que ahora no se limitan a esperar, sino que elevan una voz cada vez (sic) unánime, y por ello más clara y firme, rubricada con una creciente consecuencia en decisiones y actos, reclaman y están dispuestos a trabajar por lo suyo. En primerísimo lugar, por el respeto al Estatuto del Docente. (La Obra, jun. 1973, nº 688, p. 218).

\footnotetext{
${ }^{14}$ Cf. editoriais da revista La Obra $n^{\circ} 664$ (set. 1970) e no 670 (jun. 1971).

$15 \mathrm{Na}$ cultura do normalismo cabe à escola uma função homogeneizadora, os docentes desempenham um papel moralizador em relação à infância, assumem e transmitem os valores do Estado Nacional e buscam construir o sentido do público através da escola, entre outros traços que podem ser considerados comuns, para além das diferenças que surgiram no percurso do normalismo. A respeito do normalismo, veja-se Puiggrós (2003) e Southwell (2003).
} 
"Los tiempos están cambiando", constata-se nesse editorial cujo sugestivo título é "Tiempo de hacer", que é precisamente o que se atribui aos "maestros que han debido salir muchas veces a las calles para defender no solamente sus derechos sino también los de la escuela argentina en general". "Maestros" esses que "están expectantes y dispuestos a que este proceso se revierta; que las cosas cambien de verdad con el nuevo gobierno" (idem, p. 218). Do governo recém eleito, espera-se que realize diversas mudanças, dentre elas a de colocar em prática "el tan mentado principio de la igualdad de las oportunidades", que "exige un tratamiento democrático del problema" relativo ao tratamento igualitário das escolas e dos setores por ela atendidos; sendo por sua vez criticada a "extraña filosofía oficial" que vinha se impondo há vários anos no sentido de promover a autosustentação das escolas, deixando na mais "negra miseria a las escuelas (públicas y aún privadas)" (idem, p. 217). Nesse editorial, a bandeira da democracia tem um particular sentido social, próprio do período.

As greves docentes, que foram intensas em 1969 e 1970, são também mencionadas nesses editoriais da primeira metade da década de 1970 que aludem ainda à repressão policial. Nesse ano de 1973 consegue-se finalmente a tão ansiada "unidad docente", referida na revista pelo menos desde 1966, quando há um editorial intitulado precisamente "La unidad gremial" (abr. 1966, no 624, p. 88). Cria-se, em 1973, a "Confederación de Trabajadores de la Educación de la República Argentina" (CTERA), que desde então teve uma importante atuação nas lutas docentes. Na revista La Obra, em editorial com o mesmo título de 1966, essa unidade é assim comemorada: "saludamos con verdadera satisfacción la aparición de este organismo único", o que foi conquistado "demuestra cuál es el grado de madurez que hemos alcanzado en materia gremial" (nov. 1973, no 693, p. 553-4). O processo que culmina em 1973 com a unidade docente pode ser remontado a fins da década de 1950, é concomitante às lutas pelo aumento dos salários docentes e pela aprovação do Estatuto do Docente (BALDUZZI e VÁZQUEZ, 2000, p. 17). Mas somente em 1970 celebra-se um acordo inicial entre diferentes entidades de classe para alcançar a unidade gremial, que afinal se concretiza alguns anos depois (idem, p. 65).

Nos anos iniciais dessa década, entre as três discussões que segundo Balduzzi e Vázquez (2000, p. 53) foram centrais no movimento sindical docente, temos "las diferentes conceptualizaciones sobre el perfil socio laboral de los docentes que se traducen en la pregunta ¿trabajadores o profesionales?”. Na revista La Obra, nos editoriais, não se utiliza o significante "trabalhador" e defende-se o docente como profissional, recusando-se a ideia de apostolado como inerente ao docente, à semelhança do que se observa no movimiento sindical docente. Veja-se, por exemplo, o que se afirma no editorial de 1975 intitulado "Problemas gremiales": "las apelaciones al apostolado o a la maternidad suenan cada más huecas, más carentes de sentido, mientras que hace algunos años nos llenaban de sincera emoción" (ago. 1975, no 707, p. 322).

Ainda após o golpe de Estado de 1976, a revista mantém certo questionamento, mas atenuado e sempre parecendo medir as palavras, alegando inclusive que não perderam a fé e falando como se fossem os próprios maestros, como se observa no editorial intitulado "Dar el ejemplo", que assim começa:

Somos maestros y solemos hablar elogiosamente de nosotros mismos (...) ¡Han ocurrido tantas cosas en esta Argentina nuestra en tan pocos años! ¡Son tantos los que han perdido la fe en forma total y completa! No podemos decir nosotros, porque equivaldría a suponer que vivimos de espalda a la realidad (...) la fe que nos anima es bastante más fuerte que los cambios y los cimbronazos que nos agitan. (La Obra, jul. 1976, no 715, p. 209). 
Nesse ano, no editorial intitulado "La acción de la escuela", continua-se reclamando pelo modo como os docentes são vistos:

(...) nosotros, los docentes, somos llevados a la estratósfera o arrojados al lodo, como responsables de todos los males presentes (...) Los docentes argentinos hemos cumplido siempre en una proporción abundantísima con nuestras obligaciones. No es muy justo echarnos culpas que no merecemos ni nos corresponden" ( $L a$ Obra, set. 1976, $\mathrm{n}^{\mathrm{o}} 717$, p. 306).

Surgem ainda na revista questionamentos sobre a situação dos docentes por causa da deterioração dos salários, numa última edição onde isso é lembrado no próprio título do editorial: "Otra vez los sueldos docentes". Publicada no mês de outubro, antes da sua interrupção por um ano, nessa última edição esgrime-se ainda o que estabelece o Estatuto do Docente, afirmando-se que "sería oportuno recordar aquí el Estatuto (tan zarandeado y tan olvidado a través de sus no muchos años de vida)" (out. 1976, nº 718, p. 354).

\section{O educador na sala de aula e o norte da teoria psicogenética piagetiana}

Em 1977, a revista La Obra deixa de ser publicada e quando é retomada em 1978 já não traz questionamentos endereçados ao governo nem referências ao sindicato e suas lutas. Entretanto, ainda é possível encontrar a constatação da dicotomia existente na valoração do "maestro", junto com o incômodo que isso gera, em texto da edição de março de 1981, escrito por Jorge Fasce, o Chefe de Redação da nova etapa da revista, que havia sido comprada pela família Salas. ${ }^{16}$ Nele, assim se exprime: “

Profesión de educadores... muchas veces pensada como furgón de cola de nuestra sociedad y otras muchas idealizada como fuente de todas las esperanzas, de todos los futuros venturosos, de todos los progresos apetecibles. Empecemos por afirmar que no es ni lo uno ni lo otro. Desvalorizada y ensalsada. Subestimada y sobre-valorada. Despreciada y envidiada. Nuestra profesión ... dicotomizada, partida, escindida. Ni héroes ni oscuros transmisores de hábitos, costumbres y rutinas. Somos humildes profesionales capaces de llegar, excepcionalmente, al heroísmo (...) humildes profesionales, sí, frecuentemente atrapados por la comodidad (y el tedio) de la rutina. (La Obra, mar. 1981, n' 742, p. 4) ${ }^{17}$

Dentre as imagens que afloram dessa dicotomia à qual ainda se alude anos mais tarde, as que afinal deverão se firmar cada vez mais na década de 1980 são as que colocam o docente em questão, em discursos que desde o fim da primeira metade dessa década destacam como problema premente repensar a formação dos professores. ${ }^{18}$ Ao contrário do que se observa antes dessa nova etapa, a revista tende a não mais assumir a defesa dos docentes, pelo

\footnotetext{
${ }^{16}$ A respeito da compra da revista pela família Salas, veja-se Andrade (2016, p. 28).

17 O destaque em negrito e itálico é do autor. Cf. Jorge Fasce, "Empecemos reflexionando".

18 Essa dupla valoração do docente surge também em artigo de 1984 escrito por Francisco Cabrera, intitulado "Dificultades en el aprendizaje. La no transferencia". Assim refere-se Cabrera aos docentes: "Por un lado, sus altas calificaciones, los informes laudatorios sobre su actuación y por el otro, se entera que pese a todo, se critica su trabajo y se pone en tela de juicio sus conocimientos psicológicos y pedagógicos, incluso los didácticos." (La Obra, maio 1984, n 765, p. 117).
} 
menos não com a ênfase nem com a frequência anterior. A imagem positiva do docente fica por conta, porém, das várias experiências relatadas em artigos do período que remetem principalmente ao universo das escolas privadas "progressistas", cuja participação na revista já foi apontada por Finocchio (2009) e Andrade (2016). ${ }^{19}$ São experiências narradas pelos próprios docentes, muitas delas trazendo à tona a singularidade das situações surgidas com os alunos e nas quais sobressaem determinadas qualidades dos professores, qualidades que há muito vinham sendo valorizadas por essa publicação, como a criatividade, a abertura em relação aos alunos de maneira a contemplar seus interesses e inquietudes, a maneira flexível do docente lidar com eles e outros aspectos que, além de remeter ao escolanovismo e à histórica defesa da escola ativa por parte da revista, concernem à mudança cultural que vinha se processando com intensidade na Argentina e noutros países desde a década de 1960. Esses relatos diferenciam-se do que se observa na etapa anterior, na qual havia propostas para o professor desenvolver com seus alunos na seção "La escuela en acción", sendo basicamente prescrições sobre como o docente devia proceder e os conteúdos a desenvolver, com quadros em algumas edições relativas às chamadas planificações, divididas para o "jardín de infantes" e os diferentes "grados" (anos) do primário, com a discriminação dos meses, as áreas, os objetivos, a avaliação e outros elementos que variavam nas diferentes edições.

Além do relato de experiências ou de atividades realizadas com os alunos, uma dimensão que distingue esta nova etapa da revista e que surge como uma qualidade fundamental dos docentes é o domínio teórico que eles devem evidenciar em seus relatos e que deve sustentar as atividades que são apresentadas, de maneira que teoria e prática estejam fortemente vinculadas. A relevância dada à teoria torna-se patente logo no primeiro número de 1978, com um artigo inicial que é apresentado aos leitores num dos textos que abre a revista, à maneira de um segundo editorial, nos seguintes termos: "Este número (...) se inicia con un trabajo de reflexión teórica, PROBLEMAS LÓGICOS Y METODOLÓGICOS EN LA ENSEÑANZA DEL CÁLCULO, que da las bases para comprender los mecanismos psicológicos que entran en juego en las operaciones" (La Obra, maio 1978, no 719, p. 2). A edição inaugural dessa nova etapa é dedicada às operações aritméticas e nesse primeiro artigo, escrito por Rolando Martiña, o que é apresentado como essencial para a Pedagogia em termos teóricos é a Psicologia Genética, com destaque para as conceitualizações piagetinas (adaptação, acomodação, assimilação, estágios, etc.). $\mathrm{O}$ segundo artigo é igualmente indicativo da deriva da revista nessa etapa, pois concerne ao vínculo teoria-prática, de acordo também com o que é dito no editorial antes mencionado:

El segundo artículo, CÓMO SE ENSEÑAN LAS OPERACIONES, puede considerarse un apropiado enlace entre el planteo teórico y las notas estrictamente prácticas y didácticas que comienzan con el tercer trabajo: EL APRESTAMIENTO PARA EL CÁLCULO, de utilidad para las maestras jardineras y de primer grado. (La Obra, maio 1978, nº 719, p. 2).

Temos então, nesse primeiro número, a afirmação de determinada hierarquia, com a teoria precedendo a prática, pois conhecer as teorias que sustentam ou estão detrás das práticas pedagógicas é primordial. As práticas pedagógicas devem ser fundamentadas teoricamente e essa fundamentação tem de ser explicitada, esse é o mandato do momento: "es hora de plantear los problemas en términos de fundamentaciones y no de recetarios o 'simples sugerencias de actividades', las cuales (...) no promueven la reflexión y tienden a convertirse en pasos de una rutina análoga a la que pretenden combatir", diz Martiña naquele primeiro

${ }^{19}$ A respeito dessas escolas privadas, localizadas sobretudo na cidade de Buenos Aires, veja-se também Siede (1995) e Weinstein (2007). 
artigo. ${ }^{20}$ Recusa-se então as receitas e, além disso, exige-se que seja estabelecida uma sólida e estreita conexão entre teoria e prática.

$\mathrm{Na}$ etapa anterior, a dimensão teórica também estava presente, mas numa linguagem menos acadêmica e sem a relevância que adquire nesse momento, sobretudo a teoria psicogenética piagetiana. A referência à obra de Piaget torna-se então fundamental, assim como o emprego das conceitualizações que ele desenvolveu. Não por acaso a temática do primeiro número concerne à matemática, que podemos dizer é a área do ensino que num primeiro momento e de maneira mais direta foi vinculada à sua obra. A relevância de Piaget nesse período encontra-se relacionada com o crescente desenvolvimento de reflexões no âmbito da didática que buscam empregar suas concepções em diferentes áreas do ensino, num período em que se configura precisamente o campo das didáticas especiais. É o que pode ser notado na revista, particularmente no ano em que se dá essa emergência, no ano de 1982, quando as capas de algumas edições destacam estas temáticas: "Didáctica de la Historia" (n 752), "Didáctica de las Ciencias Naturales" ( $\left.n^{\circ} 753\right)$, "Didáctica de las Ciencias Sociales" $\left(n^{\circ}\right.$ 754) e "Didáctica de la Matemática" (n 755). Nessa etapa da revista La Obra, que seu Chefe de Redação concebia como uma "revista didáctica" 21 , cada edição era organizada em torno de um eixo temático, contando com "temas clásicos y tradicionales junto con otras propuestas poco frecuentes en las escuelas", como educação sexual e expressão corporal, conforme já constatou Andrade (2016, p. 30). Essa forma de organização da revista em parte responde à divisão por áreas do ensino ou temas relativos a uma determinada área ou disciplina, configurando assim o leito que acolhe e propicia aquela emergência.

Na revista La Obra, Piaget e suas concepções não representavam uma novidade, pois já eram relevantes na primeira metade dos anos 1970, inclusive sendo objeto de destaque nas propostas oficiais que encontraram ressonância na revista. É o que pode ser constatado na edição n 659, de abril de 1970, no artigo intitulado "Provincia de Buenos Aires. Matemática moderna", no qual consta este subtítulo: "Las recomendaciones oficiales. El pensamiento de Piaget" (p. 131). A referência a Piaget surge em artigos sobre temas como matemática, "lectoescritura" ou relativos ao trabalho no jardim de infância. Também menciona-se Piaget nos editoriais. Em abril de 1972, por exemplo, fala-se da presença de suas concepções no novo currículo de âmbito nacional $\left(\mathrm{n}^{\mathrm{0}} 677, \mathrm{p}\right.$. 66). No ano seguinte, seu nome torna-se o título do editorial (jul. 1973, $\mathrm{n}^{\text {o }}$ 689, p. 289). Diz-se então que Piaget tem 77 anos e continua produzindo, assinalando-se também que o que fez no campo da epistemologia genética é imenso. Seu nome é igualmente destacado no conteúdo listado na capa dessa edição, sendo apresentado como "una de las máximas inteligencias de este siglo". Na última edição de 1973, encontra-se ainda uma propaganda da própria revista sobre as "sorpresas" que o leitor "amigo o amiga que nos sigue" - encontrará em suas páginas no ano seguinte, dentre elas "una serie de artículos especialmente previstos para explicar a los maestros todo lo que puede ser fundamental para su trabajo, tal como se deriva de las investigaciones del eminente psicólogo y epistemólogo suizo Jean Piaget." (nov. 1973, nº 693, p. 555). De modo que já no primeiro número de 1974 surge a seção "Piaget para maestros", que aparece nas primeiras três edições desse ano ( $n^{\circ} 694$ a 696), estando a cargo de Germán Gómez, que era o Diretor da revista desde 1969 e que, como lembra Andrade (2016, p. 89), é o único autor que permanece na revista quando reiniciada em 1978. De modo que Germán Gómez, que era particularmente relevante na etapa anterior pela sua condição de Diretor e que ademais era um autor com vários textos onde prevaleciam as concepções piagetianas, é quem faz uma espécie de nexo entre uma etapa e outra, como se o tecido desse enlace fosse igualmente feito pelas conceitualizações piagetianas.

${ }^{20}$ Cf. Roberto Martiña, "Problemas lógicas y metodológicos en la enseñanza del cálculo", La Obra, maio $1978, \mathrm{n}^{\circ} 719$, p. 3 .

${ }^{21}$ Assim pelo menos referiu-se Fasce à revista La Obra em entrevista dada a Andrade em 2010 (2016, p. 31). 
Apesar dessa particular presença da obra de Piaget na revista La Obra em ambos períodos, nota-se que desde 1978 o campo da psicologia amplia-se também em outras direções, como a psicologia social, a psicologia das instituições e a psicanálise, envolvendo também o campo da psicopedagogia, que igualmente se expande. Além disso, a psicologia de maneira geral amplia sua incidência nas tramas discursivas que vão se firmar nas páginas da revista na década de $1980 .{ }^{22}$ Sobre essa maior presença é significativo o surgimento da seção Psicologia da Educação, presente em várias edições de 1981 e 1982. Em relação às concepções piagetianas, também deve-se levar em conta que na revista opera-se com elas em conjunturas políticas bem diversas, as quais às vezes incidem com força na sua linha editorial e nas formas de apropriação das referências piagetinas, em discursos pedagógicos cuja configuração se altera em diferentes momentos. São discursos que veiculam determinadas representações sobre os docentes e que entre 1978 e 1983 - e ainda no ano seguinte - pouco guardam do docente que luta por seus direitos, muito presente no momento anterior a 1976. O que sobressai na revista nesse segundo período, após 1978, é um docente cujo valor surge vinculado ao domínio que ele tem de determinadas concepções teóricas, notadamente as piagetianas, sendo também associado às experiências didáticas que desenvolve com seus alunos, relacionadas com essas concepções e realizadas por um docente cujo perfil muito deve a traços inerentes à mudança cultural que se processava nessas décadas.

\section{O docente militante de uma nova forma de vida}

Em 1982, certa inquietação começa a perpassar a revista. Um dos primeiros sinais nesse sentido, que é também o de uma realidade externa que se impõe à publicação, é o de um editorial e um texto que se referem à guerra das Malvinas. "Mientras escribimos", afirma-se no editorial, "vivimos acontecimientos que nos conmueven profundamente y nos someten a fuertes sentimientos encontrados: la satisfacción por la recuperación de las Malvinas, el horror de una guerra despiadada, la emoción de la visita de Juan Pablo II que nos deja su mensaje de paz" (maio 1982, $\mathrm{n}^{\circ}$ 751, p. 194). A guerra das Malvinas invade não apenas a revista, mas a sala de aula e o cotidiano dos argentinos, mais tarde tornando-se o acontecimento que selará o futuro da ditadura. A inquietação amplia-se nas páginas de $L a$ Obra com questionamentos antes inexistentes ou pelo menos imperceptíveis e que em 1982 são alusões que ainda não permitem identificar de maneira clara a quem são endereçadas determinadas críticas, notando-se porém que implicam as autoridades do sistema educacional em alguns de seus níveis, além das "maestras", como pode ser constatado no artigo de Cristina Bensusán de Deníes, intitulado "Reunión de padres en el jardín de infantes", presente na última edição de 1982, do mês de novembro ( $\left.n^{\circ} 755\right)$.

Nesse artigo, a autora explica como planificar e realizar uma reunião com os pais de alunos. Ademais, relata três reuniões realizadas com os pais em duas instituições diferentes. Numa dessas reuniões, as "madres" aludem ao novo currículo das escolas municipais, que muito provavelmente são as da cidade de Buenos Aires, se considerarmos comentários feitos pelas mães que correspondem a críticas que se avolumam nos anos seguintes sobre a lentidão imposta às crianças em seu processo de alfabetização, dado que as "maestras" deviam limitar o número de letras a ensinar. Trata-se do currículo que passou a ser conhecido como currículo das "13 letras" (CARUSO e FAIRSTEIN, 2003, p. 202). Estes são alguns dos comentários das mães reproduzidos no artigo:

\footnotetext{
${ }^{22}$ Sobre a psicologização do discurso pedagógico na Argentina nessas décadas e a presença de Piaget nesses discursos, veja-se Caruso e Fairstein (2003).
} 
- Formados como soldados, con el cabello engominado, duros, los he visto yo.

- Se desvaloriza al niño, lo retan constantemente y por último no reacciona ante nada.

- En los colegios Municipales sacaron muchas horas especiales y los chicos "hacen tiempo", no se los estimula (...)

- Si han sacado profesores especiales por problemas económicos, mucho menos van a poner profesores para talleres y los maestros están agotados (...) (La Obra, nov. 1982, no 755, p. 627)

O ano de 1983 inicia-se promissor, a volta da democracia nutre a revista de renovadas esperanças. O primeiro editorial do ano refere-se à "Argentina de 1983, después de tantas frustraciones, de tantos dolores, de tantos desalientos", e diz que esse "número de La Obra pretende ser una humildísima contribución a esas esperanzas que deben serlo de mejores conocimientos, de sentimientos más intensos, de ilusiones más fecundas, de instituciones más creativas, de buena educación para todos" (mar. 1983, $\mathrm{n}^{\mathrm{o}} 756$, p.2). ${ }^{23}$ Com o impulso dado pelo que se avizinha, a revista mobiliza então, no mesmo editorial, o significante "utopías":

Pensamos que para progresar es necesario mirar un poquito más allá del horizonte sin dejar de pisar el terreno inmediato: las utopías tienen la función de inquietar, de conmover, de sacudirnos la rutina (...). En este número, se presentan varias experiencias que pueden parecer utopías, que seguramente son innovaciones, realizables hoy en algunos ambientes, quizás impracticables en otros pero siempre nos sugerirán nuevos rumbos (...). (La Obra, mar. 1983, nº 756, p.2). ${ }^{24}$

Uma dessas experiências mencionadas no editorial, que é precisamente a do artigo que abre essa edição, é o relato da história de uma escola cooperativa que pertence ao universo de escolas privadas "progressistas": a escola Mundo Nuevo. ${ }^{25}$ Esse relato constitui o pontapé inicial de uma temática que deverá ter alguma relevância na revista até pelo menos 1986, em artigos que se referem ao cooperativismo, precedida por certo valor que vai adquirindo o olhar sobre o grupo e as relações interpessoais, no âmbito da sala de aula e da escola, envolvendo docentes, alunos, direção da escola e pais de alunos. Concerne ainda a uma dimensão da educação escolar que ganha terreno nessa década, que é a da escola enquanto instituição. Além do docente, em discursos que circulam na Argentina nesse período, começam a recair sobre a instituição escola as responsabilidades e avaliações depreciativas associadas aos problemas da educação escolar, de forma concomitante à avaliação do Estado como uma instância burocratizada e autoritária, que com a retomada da democracia é frequentemente vinculada à ditadura, segunda uma deriva discursiva que nutre a desvalorização da escola pública e fortalece o prestígio das instituições de ensino privadas, de acordo com o que constata Garaban (2009).

O período que se inicia com o retorno da democracia abre na revista um conjunto de temas que giram em torno da articulação entre educação e democracia. Aos docentes, principalmente, cabe-lhes a responsabilidade de forjar os cimentos da vida democrática na sala de aula, na escola e também fora dela. Falar do docente democrático não constitui uma novidade na revista, falava-se nesses termos durante a ditadura, mas a reflexão tende a ficar

\footnotetext{
${ }^{23} \mathrm{O}$ destaque em negrito é da revista.

${ }^{24}$ Os destaques em negrito e itálico são da revista.

${ }^{25}$ Trata-se de uma "escola progressista laica", de acordo com a denominação utilizada por Siede (1995).
} 
circunscrita ao âmbito da sala de aula. ${ }^{26}$ A partir de 1983, porém, esse âmbito é ampliado. Fica então em pauta a sociedade democrática, a comunidade democrática, a escola democrática, a paz democrática, a forma de vida democrática. Uma profusão de termos que estendem a discussão e a extensão do significante democracia em diversas direções nos anos seguintes, com tensões e conflitos que neles retêm os dilemas da incipiente instauração da democracia, com todos os problemas institucionais que isso acarretou.

Com a volta da democracia, a pretensão de viver numa sociedade democrática tem "una nueva oportunidad", de acordo com o que destaca o breve texto que antecede o título do artigo "Problemas para maestros", cujo autor é Néstor Abramovich. "¿En qué medida podemos empezar a construir, en las escuelas argentinas los cimientos de ese nuevo edificio nacional? ¿Cómo hacerlo?” (La Obra, set. 1983, n 761, p. 58). Essa é a interrogação dirigida aos "maestros" que precede o início do texto. A resposta perpassa esse e outros artigos, em vários deles pondo-se em pauta que democracia é debate e conflito ou, como salienta Abramovich, "la paz democrática es ruidos, porque vive (...) es la antítesis del silencio sepulcral de las tiranías" (idem, p. 60). Essa perspectiva convive nas páginas da revista com outras, por vezes contrastantes, mas em artigos que pouco deixam transparecer conflitos ou tensões entre elas.

Uma visão diferente da delineada por Abramovich encontra-se, por exemplo, num artigo de 1985, no desdobramento que é peculiar a esse ano, quando o significante comunidade sobressai na capa da revista em sete de seus nove números no tema então em destaque nas capas dessas edições: "El niño y su comunidad". Intitulado "La escuela y la comunidad", o artigo escrito por Francisco Cabrera constata que nos últimos tempos a combinação dos termos do título "presenta un aditamento: La escuela en la comunidad democrática; La escuela democrática y la comunidad; Democracia en la escuela y en la comunidad" (La Obra, abr. 1985, $\mathrm{n}^{\mathrm{o}} 772$, p. 123). ${ }^{27}$ E, para assinalar a extensão desse "aditamento" relativo ao significante democracia, assim continua: "Como buena costumbre nuestra, se nos ha pegado en los labios, y sin reflexionar demasiado" (idem). Diz, ademais, que "Hace mucho tiempo que se habla de comunidad, y de comunidad escolar. Pero el alcance que se le otorgó a esa frase es totalmente diferente del que puede y debe tener" (idem). Para Cabrera, o "concepto Comunidad-Escuela implica la necesidad de comprender que ambas instituciones tienen intereses y tareas comunes, que son las que las relacionan" e elas têm "que clarificarse cuanto tienen de común en relación con la Educación, en qué medida ambas tienen que contribuir para que la sociedad funcione como un todo coherente. La coherencia es indispensable en un sistema para que éste funcione bien" (idem, p. 124). Como se vê, no artigo de Cabrera também está em pauta a democracia, nesse caso como que sobrepujada pelo modo como conceitualiza a comunidade. E nesse registro, ao contrario do que enfatizava Abramovich, o acento é colocado na busca de coerência, de harmonia, de unidade sistêmica.

A série de significantes e temas que emergem ou retornam junto com a questão da democracia é diversa, enfatiza-se a liberdade, a luta contra o autoritarismo, a formação de sujeitos críticos e comprometidos com a transformação da sociedade. A dimensão política da educação alcança nesse período um primeiro plano e surge atrelada à forte lembrança da última ditadura militar, como evidencia em seus artigos Guillermo García, em especial em 1985, no ano em que ocorreu o juízo aos comandantes militares que governaram a Argentina

\footnotetext{
${ }^{26}$ Um exemplo é o artigo de Oscar Bosetti, "Grupos y liderazgos" (abr. 1980, n 735, p. 15). Nele, a partir da perspectiva da Psicologia Social, o autor define o que entende por grupo e concebe "el aula como grupo social" (p. 17). Discute então o que é um líder e os tipos de lideranças relativos aos diferentes tipos de "maestros" e reações dos alunos: autoritária, paternalista, laissez-faire e democrática (p. 17-21). Para o autor, o "maestro" é um líder emergente e é fundamental que ele se realize como líder emergente, para alcançar "un funcionamiento más efectivo y eficiente" (p. 17). Dentre os tipos de "maestro", o que o autor valoriza é o "maestro democrático".

${ }^{27} \mathrm{O}$ destaque em negrito é da revista.
} 
durante a ditadura e quando já era conhecido o informe Nunca Más, publicado no final do ano anterior. Num desses artigos, presente na seção "Escuela y Comunidad", com o título "La escuela democrática", García refere-se assim à última ditadura:

En la Argentina hemos llegado a pensar, o al menos así han intentado hacernos creer en algún momento, que podíamos renunciar a la democracia y a las libertades. El precio ha sido muy alto: en su lugar hemos visto que la violencia y la muerte se abatían sobre nosotros. De las grandes tragedias históricas los pueblos recogen las grandes lecciones y la nuestra ha sido que debemos forjar una nueva forma de vida, donde las instituciones democráticas en funcionamiento son un presupuesto necesario pero no suficiente. Nos falta aún el duro aprendizaje de la libertad y del amor, para que nunca más vivamos la opresión y el miedo. (La Obra, mar. 1985, nº 771, p. 136) ${ }^{28}$

Mencionar o "nunca más" nesse momento tinha a suas particulares ressonâncias em qualquer argentino minimamente conectado com os temas de natureza política que repercutiam na mídia e nas conversas do dia-a-dia. E García faz ecoar esse significante num discurso que coloca como prioridade a criação de uma nova "forma de vida", uma forma de vida democrática. Esse, precisamente, é o registro em que no decorrer desses anos tende-se a pensar a democracia nas páginas da revista, como forma ou estilo de vida. Em García surge também com força a figura do militante, quando afirma que "la forma de vida democrática supone la militancia política de todos los ciudadanos" ${ }^{29}$, sem que essa formulação suponha necesariamente a participação num partido político, pois a entende em termos mais amplos, como uma responsabilidade que se assume como cidadão em qualquer campo da vida social (La Obra, mar. 1985, $\mathrm{n}^{\circ}$ 771, p. 134).

Essa dimensão da militância política é destacada num outro artigo de García publicado no mesmo ano, na mesma seção, desta vez intitulado "Docencia y militancia" (maio 1985, n' 773, p. 120). No texto explica o que entende por militante e destaca a importância da dimensão política e os riscos de ignorá-la: "hay toda una dimensión política (...) en la tarea docente que no puede ser ignorada o subestimada, a riesgo de convertirnos en meros técnicos de la instrucción, sin un enfoque global de la educación como práctica social inserta en una circunstancia histórica específica" (idem). ${ }^{30}$ No caso dos docentes, militar "equivale a asumir la tarea de mejorar y transformar nuestra escuela para que (...) sea una escuela democrática y para la democracia", "los docentes somos militantes de la libertad y la democracia" (idem, p. 120-1). Para García, o militante é um lutador, em um campo de luta que é pacífico e voltado para a paz, e tem como qualidade essencial a solidariedade. Sobre o docente como militante, outras qualidades são apresentadas e explicadas: participante, cooperativo, criativo, crítico. São qualidades que vincula a diferentes âmbitos de atuação do docente: o pedagógico, o institucional e o sindical. Nesta última instância retorna o que havia adquirido especial significado entre os docentes e na própria revista dez anos antes e que agora García concebe nestes termos: "la actividad gremial es la instancia de acción y participación política de que disponemos los docentes para defender nuestros derechos y asociarnos para nuestro desarrollo profesional" (idem, p. 122). Naquelas três instâncias García entende que o docente deveria atuar imbuído de sua "pasión militante", uma "pasión" necessária à renovação da escola com o horizonte posto no que nesse momento ganha relevância: a criação de uma nova forma de vida, um "estilo de vida basado en la libertad y en la convivencia" (idem).

\footnotetext{
${ }^{28} \mathrm{O}$ destaque em negrito é do autor.

${ }^{29} \mathrm{O}$ destaque em negrito é do autor.

${ }^{30} \mathrm{O}$ destaque em negrio é do autor.
} 
Esse parece ser o principal registro da incipiente democracia dos anos 1980 que a revista assume e que difere daquele que estava em pauta nos anos 1970, antes do golpe militar de 1976. A relevância desse registro, que se encontra também em outras publicações ${ }^{31}$, em boa parte parece implicar as transformações culturais que inicialmente envolveram o setor das camadas médias que alavancou e nutriu o campo das escolas privadas "progressistas", cuja presença na revista La Obra era particularmente expressiva no momento anterior, quando o Chefe de Redação era Jorge Fasce. ${ }^{32}$ De modo que nessa intenção de criar uma nova forma de vida como horizonte para a escola temos, ao que tudo indica, o prolongamento de certo percurso e de questões que já vinham sendo trabalhadas nesse universo escolar, onde aspectos da mudança cultural se entrelaçaram com as questões de ordem política e ideológica próprias desse setor social. ${ }^{33}$

Nesse período, quando o significante democracia tende a ordenar boa parte dos discursos, incluídos os pedagógicos, na revista La Obra continua a se falar do docente como profissional, mas o que a sua atividade como profissional tende a abarcar amplia-se muito, a começar pela dimensão política antes ressaltada. ${ }^{34} \mathrm{~A}$ realidade à qual incita-se o docente a dirigir seu olhar, suas expectativas, suas lutas e em relação à qual demanda-se que assuma maiores responsabilidades extrapola a sala de aula, a escola e as famílias. Implicar-se e estar atento a essa realidade, como demanda feita ao docente, surge nesse momento com todo o peso da história recente, envolvendo as sequelas da ditadura e de seu fim, com a guerra das Malvinas. É sintomático a esse respeito as opções editoriais da revista La Obra entre 1984 e 1986, se as entendermos como estratégia editorial e pedagógica sensível a esses acontecimentos.

Em 1984, a revista destaca certos temas nas capas sobre determinada efeméride do mês em curso, um em cada edição: : "La revolución de Mayo" ( $\left.n^{0} 764\right)$, "20 de Junio - Día de la Bandera" (em referência a Manuel Belgrano; $n^{\circ} 765$ ), "Declaración de la Independencia" (n'766), "El cruce de los Andes" (em referência a José de San Martín; no 767), "Maestro ..." (em referência a Domingo Faustino Sarmiento; no 768), "Descubrimiento de América" (em homenagem a Espanha, "madre de naciones", nas palavras do editorial; n 769) e "Día de la Tradición" (em referência a José Hernández, autor do Martín Fierro; no ${ }^{\circ} 770$ ). Exaltar as virtudes nacionais, os heróis, o valor da pátria e dos que a forjaram, com suas tradições, corresponde a uma opção editorial cuja definição e implementação parece particularmente vinculada à derrota na guerra das Malvinas e ao fim da ditadura, quando essa exaltação estava também em jogo, embora de um outro modo, com outros elementos e num outro registro. Busca-se nesse momento colocar em primeiro plano a história e a cultura nacionais no que elas teriam de melhor. Discrimina-se então, na seção intitulada "Calendario escolar", presente em todas as edições desse ano, determinados fatos históricos, acontecimentos ou

\footnotetext{
${ }^{31}$ Na própria revista La Obra nota-se a presença desse viés em outras publicações, pois por vezes publica matérias de outros periódicos, como ocorre em la última edição de 1985, no texto intitulado "La escuela democrática", cuja fonte explicitada pela revista é Puerta Abierta $\mathrm{n}^{\circ}$ 1, apresentada como "Publicación del Centro Provincial de Documentación e Información Educativa. Consejo Provincial de Educación de Rio Negro" (n 779 , p. 8 e 9). Nessa edição não consta o mês de publicação.

32 A partir de junho de 1983, sucedendo Jorge Fasce, há um novo Chefe de Redação: Jorge Propato, que permanece até a última edição de 1985. Em 1986, na ficha técnica não consta nenhum Chefe de Redação, embora exista a função de Secretário de Redação, desempenhada por Rodolfo Saldaño, que já fazia parte da equipe com essa mesma responsabilidade desde 1985. No início de 1987, Jorge Propato retorna como Chefe de Redação e fica até setembro de 1988. Um novo Chefe de Redação assume em janeiro de 1989: Alberto Pujol, que desempenha essa função até maio de 1994. Nesse período, mas já desde 1978, Carlos Guillermo Salas é o Diretor-Editor da publicação.

${ }^{33} \mathrm{Cf}$. Siede (1995).

${ }^{34}$ Southwell (2002, p. 40) refere-se à presença do significante democracia na "primera etapa de la transición democrática", na Argentina, nos seguintes termos: "El alfonsinismo construyó su hegemonía alrededor del significante democracia. Democracia ocupó el lugar central de todos los discursos de la época”.
} 
personalidades vinculando-os a cada dia do mês correspondente, junto com um breve texto que explica seu valor e significado.

A proposta didática da revista em 1984 é que cada efeméride funcione como um "eje motivador", com a intenção de que "gire sobre él todo el proceso enseñanza-aprendizaje", conforme assinala o editorial do mês de julho desse ano $\left(n^{\circ} 767, p .2\right)$. E a revista é organizada para responder a essa proposta didática, que nesse ano busca a "integração absoluta" entre as disciplinas ou áreas envolvidas nos processos de ensino-aprendizagem, dando assim um renovado ímpeto ao que nos discursos pedagógicos presentes na revista e em outras publicações constitui uma espécie de leitmotiv que atravessa várias décadas, em cada momento ganhando uma feição diferente, em arranjos discursivos diversos, envolvendo significantes e conceitualizações que buscam superar as divisões entre disciplinas e que mudam ao longo desses anos. Na revista La Obra fala-se, por exemplo, dos "centros de correlación" na primeira metade dos anos 1970, de integração na década seguinte e de interdisciplinaridade desde fins dos anos 1980 e na década de 1990. Surgem também estratégidas didáticas que apontam no mesmo sentido e que por vezes renovam ou apenas retomam determinadas tradições, como os centros de interesse na educação infantil (como se vê nos anos 1960 e na década seguinte) ou o "método de projetos", que renova a tradição escolanovista e está presente nos anos 1980, mas com forte repercussão somente na década de 1990, na sua segunda metade.

Em 1985, há uma nova mudança na estrutura da revista e na proposta didática que com ela se relaciona, implicando também a preocupação com a integração das áreas envolvidas nos processos de ensino-aprendizagem, como se dizia nesse momento. Propõe-se aos docentes que desenvolvam seu trabalho a partir de um "núcleo central" definido como "El niño y sua comunidad", que, como já apontado, está presente na maioria das nove edições desse ano (do $\mathrm{n}^{\mathrm{o}} 1$ ao $^{\mathrm{o}} 7$ ). Conforme se vê no primeiro editorial de 1985, a revista La Obra propõe uma gradação no estudo das comunidades, partindo da criança, sua família e sua escola, depois a criança e sua comunidade local (cidade, bairro, etc.), para continuar com a criança e sua comunidade "provincial", a criança e sua comunidade nacional e a criança e seu país, na relação com outros países. Além disso, cada uma dessas sete edições da revista destaca um "eje motivador" relacionado com o núcleo central, tais como: "Así es mi comunidad" ( $\left.n^{\circ} 771\right)$, "Los pobladores de mi comunidad" ( $\left.{ }^{\circ} 772\right)$ e "Como se organiza mi comunidad" ( $\left.\mathrm{n}^{\mathrm{o}} 773\right)$, entre outros. Ainda no primeiro editorial, onde a nova estrutura e a consequente proposta didática é apresentada, afirma-se que nos números desse ano serão aprofundados, nas diferentes comunidades, "sus aspectos básicos, paisaje natural, población, pasado y presente, su realidad y su futuro, salud y vivienda, trabajo y recreación" (mar. 1985, $\mathrm{n}^{\circ}$ 771, p. 3). E, como "principios implícitos" dessa proposta, são indicados estes três: "regionalización", "renovación curricular" e "educación permanente" (idem).

Nesse breve delineamento da opção editorial desse ano, nota-se que ao docente é demandado que dirija seu olhar para a comunidade onde está inserida a escola e à qual pertence à criança; seu trabalho deve ser articulado tendo em vista essa realidade que ultrapassa a criança. Um olhar que também supõe atentar para certa diversidade regional e local, segundo uma perspectiva que supõe a definição de um currículo que deve ser regionalizado, envolvendo também uma maior autonomia da escola. Nesse período, diversas reformas curriculares começam a ser implementadas em diferentes províncias pelas novas autoridades. São reformas que alteram proposições que vigoraram durante a ditadura e elas são divulgadas nas páginas de La Obra, notadamente desde fins de 1985 e no ano seguinte. Nesse mesmo período surgem também fortes críticas ao currículo que havia sido implementado na cidade de Buenos Aires no início dos anos 1980, no qual a obra piagetiana tinha sido objeto de uma particular apropriação, severamente questionada. 
No rumo que o significante comunidade estabelece em 1985, na sua particular articulação com a questão da democracia, candente nesse momento, vê-se emergir a figura de Paulo Freire, no editorial do último número do ano (La Obra, no 779). Nessa edição, o que está em foco é o docente, que assim é destacado na manchete de capa: "El autoperfeccionamiento y actualización del docente". No editorial, cujo título é "Educación para la libertad", precedido em letras menores pela expressão "Renovación Educativa", são brevemente apresentados os artigos dessa edição e depois fala-se sobre "La educación en nuestro tiempo", que é o subtítulo do tema que a seguir é desenvolvido (idem, p. 3). O editorial começa então lembrando que é fundamental reler certos textos cujos conteúdos são vitais em todas as épocas e expõe em seguida qual a intenção dessa parte do editorial: "reflotar conceptos muy importantes sobre 'la educación de ahora y de todos los tiempos', la educación de y para la libertad" (idem). ${ }^{35}$ Nomeia então "eminentes pedagogos" que sustentam suas ideias, dentre eles Paulo Freire, Jean Piaget, Hans Aebli e Luis Jorge Zanotti. A seguir, afirma-se que a "tradicional estructura vertical del sistema escolar, cargada de autoridad e imposición, cede el paso a una visión horizontal, amistosa y orgánica, de relaciones entre los integrantes de la comunidad educativa" (idem, p.4). E refere-se num tom crítico aos "métodos didácticos" que "están más preocupados por la transmisión de los conocimientos que por la creación (...) de un espíritu crítico" (idem).

Após essas primeiras linhas, são então esboçadas algumas concepções diretamente associadas a Paulo Freire, que é na verdade o "pedagogo" que se busca destacar, inclusive mantendo-o implícito na parte inicial do texto, se repararmos nos significantes que são mobilizados, a começar pelo título do editorial, que lembra o livro de Freire Educação como prática da liberdade. Logo depois de atribuir-lhe uma "visión orgánica" da educação, "que debe surgir en un ambiente de perfecta integración, de relaciones internas que se conjuguen con la comunidad", o editorial reproduz um conhecido trecho do livro Pedagogia do Oprimido, mas sem que a fonte seja mencionada: "nadie educa a nadie, nadie se educa solo, nos educamos los unos a los otros, mediatizados por el mundo" ( $L$ a Obra, 1985, no 779, p. 4). ${ }^{36}$ São também assinalados alguns objetivos básicos do processo educativo, salienta-se a distinção entre uma consciência ingênua e uma consciência crítica, ressalta-se a importância do "diálogo educativo" e da dialética "reflexión-acción-reflexión" e são mencionados os nomes do que se concebe como uma "nueva visión educativa": "educación liberadora", "educación concientizadora" e "educación problematizadora" (idem, p. 4). Por último, na parte final do editoral, são apresentadas algumas definições de educação afins à perspectiva delineada, como esta: "La educación no es solamente un instrumento para transmitir el patrimonio cultural de un grupo humano, sino sobre todo el instrumento para mejorar, renovar y transformar esos valores recibidos" (idem, p.5).

Essa definição, assim como o que antes foi mencionado sobre o "método didático", estão no cerne de certo debate que surgiu na Argentina nesse período, pouco tempo depois de um debate semelhante se desenrolar no Brasil. E dele poucos vestígios podem ser encontrados na revista La Obra, sendo necessário procurá-lo nas entrelinhas. O que nesse momento estava em pauta era a articulação entre educação e democracia e, com ela, a definição da função precípua da educação escolar, envolvendo basicamente o campo dos discursos qualificados de críticos. No Brasil, o início da polêmica vinculada a essa articulação remete aos textos publicados por Dermeval Saviani no início dos anos 1980, primeiro na revista ANDE e depois no seu conhecido livro Escola e Democracia. Esses textos foram também publicados na Argentina na Revista Argentina de Educación, o primeiro em 1983 ("Las teorías de la educación y el problema de la marginalidad") e o segundo em 1987 ("Escuela y Democracia o

\footnotetext{
${ }^{35} \mathrm{O}$ destaque em negrito é da revista.

${ }^{36} \mathrm{O}$ destaque em negrito é da revista.
} 
la teoría de la curvatura de la vara"). ${ }^{37}$ A repercussão dos textos de Saviani na Argentina, com críticas que colocavam em questão várias concepções, como as que procediam dos discursos que ele situava em linha de continuidade com o escolanovismo, como a educação popular associada à obra de Paulo Freire e o campo dos discurso alternativos, é constatada por alguns autores, como Davini (2010, p. 32), que destaca a influência das "posiciones del intelectual brasileño" na década de 1980 e a sua "profusa circulación en nuestro medio - al menos en los ámbitos universitarios -, decisiva en la formación de los discursos".

Davini refere-se, em particular, ao "muy difundido trabajo" onde Saviani alude à teoria da curvatura da vara e no qual "sostiene que la pedagogía tradicional, centrada en la inculcación del conocimiento (...) fue la pedagogía más democrática”; enquanto concebe como "antidemocrática la pedagogía de la Escuela Nueva o Escuela Activa" (idem). Nessas teses defendidas por Saviani, um ponto que sobressai e que será decisivo na identificação de suas posições é o papel e a importância dos conteúdos do ensino, da transmissão de conhecimentos socialmente significativos pela escola, em particular pela escola pública, que é a frequentada pelos setores populares. Daí o nome, precisamente, da concepção que ele e outros intelectuais brasileiros buscam delinear, a chamada pedagogia crítico-social dos contéudos, mencionada também por Davini (2010, p. 46).

A repercussão dos artigos de Saviani na Argentina é igualmente destacada por Suásnabar (2013, p. 214-5), em particular o primeiro, onde divide as teorias da educação em não-críticas e críticas. Para Suásnabar (idem, p. 214), trata-se de um "texto clave" que "en los primeros años de la democracia se convertirá en bibliografía recurrente en las cátedras universitarias". Nele, Saviani "decretaría la muerte" das "corrientes reproductivistas" (SUÁSNABAR, 2013, p. 214) ou do que ele denomina "teorias crítico-reprodutivistas", as quais "chegam invariavelmente à conclusão de que a função própria da educação consiste na reprodução da sociedade em que ela se insere" (SAVIANI, 1984, p. 19-20).

A crítica ao reprodutivismo, assim como a crescente discussão sobre a importância de determinados conteúdos que caberia à escola ensinar, já vinham ganhando terreno em textos de intelectuais argentinos, mas com uma circulação relativamente restrita, como os de Cecilia Braslavsky e Juan Carlos Tedesco (SÚASNABBAR, 2013, p. 183-215). ${ }^{38}$ Os artigos de Saviani, porém, talvez por sua "virtud comunicativa", com diz Suásnabar (2013, p. 214), parecem ter sido fundamentais para a divulgação e ampliação do debate sobre esses pontos, especialmente a questão relativa à relevância dos conhecimentos a serem transmitidos pela escola - uma questão vinculada na Argentina à denúncia do esvaziamento desses conteúdos nos circuitos diferenciados de escolarização dos setores populares.

A importância e o papel dos conteúdos escolares relaciona-se nesse período com o valor que a dimensão política vinha adquirindo com o fim do regime militar e conforme entra em pauta o tema da democracia, a sua articulação com a educação e desta com a política. Essa articulação é particularmente relevante nos textos de Saviani. Na sua perspectiva, "a importância política da educação reside na sua função de socialização do conhecimento" (SAVIANI, 1984, p. 92). Diferente, portanto, do que sobressai na revista La Obra no período aqui focalizado. O que nela tende a prevalecer liga-se estreitamente ao que em suas páginas emerge como essencial nesse momento: a criação de uma forma de vida democrática, guardando assim certa semelhança com o que estava no horizonte dos discursos educacionais alternativos que circulavam no Brasil entre fins dos anos 1970 e inícios da década seguinte (REVAH, 1994).

\footnotetext{
${ }^{37}$ Cf. Revista Argentina de Educación n 33 (set. 1983) e no 8 (jun. 1987).

${ }^{38}$ Relacionado com a discussão desses temas na Argentina, Suásnabar (2013, p. 213) também menciona um texto de Guiomar Namo de Mello escrito em espanhol: "Las clases populares y la institución escolar: una interacción contradictoria”, publicado em 1985 no México, no livro Educación y clases populares en América Latina, organizado por María de Ibarrola e Elsie Rockwell.
} 
A discussão gerada em torno dessas concepções que Saviani demarca e opõe, dando lugar a um debate que parece ter sido mais intenso no Brasil do que na Argentina, pouco aparece na revista La Obra. Apesar disso, a preocupação com o que nele está em causa pode ser percebida pelo menos desde fins da primeira metade dos anos 1980. É o caso de um artigo de 1983 intitulado "Para hablar claro: discursos", que contém, entre outros, o discurso feito por uma docente de um "Profesorado de Educación Pré-escolar" no "Día del Maestro" (La Obra, set. 1983, n $\mathrm{n}^{\mathrm{0}}$ 761). Ao referir-se ao "rol" do "maestro", sugere que ele inclui "un hondo compromiso con los 'contenidos' de la educación pero, por sobre todas las cosas, con la preocupación por las personas totales involucradas en ese proceso" (idem, p. 64). Na revista La Obra nota-se uma significativa presença dos conteúdos escolares clásicos, com variações em diferentes momentos, como as que foram assinaladas quando surgem os "ejes motivadores". Portanto, numa primeira avaliação, a dimensão dos conteúdos não parece ficar relegada, mesmo quando a ênfase tende a ser colocada na criação de uma forma de vida democrática e no trabalho com os valores em jogo nas práticas educacionais.

\section{O "maestro" em questão}

Em 1986, na temática central das edições desse ano, nota-se que continua o apelo ao docente para que considere a "realidade", agora a "sua" realidade, que inclui dimensões que já vinham sendo destacadas, como a "comunidade". Em sete dos nove exemplares desse ano, as capas contêm em sua parte superior este tema: "El maestro y su realidad". Além disso, em cada uma dessas sete edições é abordada uma temática específica, realçada também na capa, como "La organización de la tarea docente" $\left(n^{\circ} 780\right)$, "El binomio educativo niño maestro" (n $\left.{ }^{\circ} 781\right)$, "La comunidad escolar democrática" ( $\left.n^{\circ} 783\right)$ e "La acción sociocultural del docente $\left(n^{\circ} 784\right)$. Observando alguns desses temas centrais já se percebe que aquela dimensão ampla da "realidade" continua em pauta, com a democracia sendo ainda um tema bem presente. Mas o que antes de mais nada sobressai é o "maestro", ele é o principal protagonista, segundo um percurso que é o de um crescente questionamento sobre a sua atuação e também da sua formação, envolvendo a chamada "capacitación", "actualización" ou "perfeccionamiento".

As críticas aos docentes adensam-se conforme avançamos na década de 1980, vários são os questionamentos, mas os que se destacam pela sua recorrência põem em causa o chamado "rol" docente, a "función" do professor e mais ainda, a sua "personalidad", o docente como "persona". Esses, aliás, são os significantes que mais parecem ressoar nessa década nas páginas de La Obra para demarcar o que o docente deve mudar nele próprio. São significantes que remetem ao que é da ordem das suas atitudes e comportamentos, ao modo como o docente se posiciona e se relaciona com seus alunos, envolvendo características da sua personalidade. São dimensões que muito ultrapassam as questões estritamente didáticas ou pedagógicas e um olhar histórico permite situar o que dele se demanda na esteira das transformações culturais que vinham se procesando desde os anos 1960 e que se entrelaçam com os discursos "psi”, que em grande medida acabaram sobrepujando-as para inscrevê-las num registro que fica sob seus parâmetros. Desde aquela década, pelo menos, na revista incentiva-se o docente a mudar suas atitudes e comportamentos e o que constitui uma referência essencial para que empreenda a transformação que dele se espera, em si mesmo e no modo como exerce o magistério, é a criança-aluno ou mais precisamente, as representações que dela e a partir dela são feitas e que por vias diversas incidem na transformação da docência.

Nesse complexo processo, a pretendida mudança do professor como pessoa tende a ficar no registro do construtivismo na segunda metade dos anos 1980, como é possível notar nesta declaração feita em 1987 pelo conhecido articulista de La Obra Guillermo García, que assim se refere à mudança que ocorre nas "maestras" quando assumem a nova perspectiva que 
ele próprio busca delinear nas páginas da revista, chamando-a de modelo didático construtivista ou pedagogia construtivista: "las que cambiaron, no sólo cambiaron los métodos sino que cambiaron ellas como personas" $\left(1988, \mathrm{n}^{\circ} 803, \mathrm{p} .43\right){ }^{39}$ García atribui a mudança ocorrida nas docentes ao que é da ordem da pessoa, como é próprio de boa parte dos discursos pedagógicos da revista nessa década de 1980. Nessa década, procura-se efetivar essa mudança sobretudo por meio de uma estratégia: a forma "taller" (oficina), na qual o professor precisa "fazer", atuar, tomar a iniciativa, vivenciar determinadas situações. ${ }^{40}$ Essa estratégia é largamente reiterada e promovida na revista, principalmente para que os docentes a utilizem com os alunos, sendo inclusive destacada nas capas de várias edições.

$\mathrm{O}$ que se encontra implicado na mudança que se busca promover no docente muito extrapola o âmbito didático e pedagógico e seria possível rastrear parte considerável das atitudes que dele se exige em representações presentes na revista em anos e décadas anteriores. A exigência feita ao docente no sentido de escutar os alunos, ser aberto, flexível, afetivo e outras qualidades faz parte em boa medida da mudança cultural que envolveu primeiramente as camadas médias, fazendo-se presente com intensidade nas escolas privadas "progressistas", que na revista La Obra estão particularmente presentes nos relatos de experiências feitos por docentes entre 1978 e 1983, quando essas escolas tiveram uma maior participação nessa publicação (ANDRADE, 2016). Ainda não se falava do construtivismo nesse período em referência a propostas ou perspectivas pedagógicas, nem encontrava maior ressonância a pesquisa de Ferreiro e Teberosky sobre a psicogênese da língua escrita (1986), cuja divulgação foi - ao que tudo indica - fundamental na emergência do novo discurso pedagógico que o significante construtivismo demarca e ordena, como se observa na revista La Obra e também no Brasil (REVAH, 2004), em particular na segunda metade dos anos 1980. Entretanto, o que sim já estava bem presente era o viés piagetiano, mas também experiências enraizadas em certo universo cultural. ${ }^{41}$ Esse tipo de relatos de experiência, que traziam à tona a vivacidade e singularidade do que acontecia na sala de aula, com "maestras" que evidenciavam sua criatividade, sua maneira divertida de conduzir uma atividade e que aproveitavam as iniciativas das crianças para inventar novas atividades tende a diminuir nos dois anos seguintes, quando no lugar de experiências surgem propostas, por vezes dizendo-se que são relatos de experiências, mas que na verdade são propostas nas quais predomina um viés prescritivo. Os relatos de experiência, porém, com aquelas características do período que se estende entre 1978 e 1983, voltam de certo modo conforme García busca delinear o modelo didático construtivista e dá lugar a experiências que seriam o exemplo vivo da implementação desse modelo, com docentes que são de escolas públicas e que inclusive devem sua formação a professores como García. Esse é o momento em que novos especialistas começam a se destacar na formação dos docentes, a partir de então "maestros" construtivistas. Esse, aliás, é outro tema importante nas edições da revista desse período: a relação entre especialistas e investigadores, de um lado, e docentes, do outro.

\footnotetext{
39 Essa declaração foi reproduzida em 1988 pela revista La Obra, junto com outros fragmentos de uma entrevista dada por García e inicialmente publicada na revista Palabra abierta (1987, ano 1, n 1).

${ }^{40}$ Um bom exemplo da relevância que adquiriu o "taller" na formação docente na Argentina é a edição inaugural do periódico Novedades Educativas, que ao que tudo indica teve uma boa acolhida entre os profissionais da educação. Lançado em março de 1989, com informações sobre o sistema educativo argentino, como destaca Finocchio (2009, p. 172), a referência ao "taller" surge na única foto da capa inaugural, que ainda anuncia como destaque do futuro segundo número uma matéria cujo título contém esta questão: “Qué es un taller?”. Além disso, no editorial dessa primeira edição, o próprio periódico é qualificado de "publicación-taller" (p. 3).

${ }^{41}$ Refiro-me ao universo cultural delimitado pelo setor das camadas médias que frequentava as já mencionadas escolas privadas "progressistas" e cujo perfil pode ser aproximado das que no Brasil foram qualificadas de "alternativas", como as que surgiram na cidade de São Paulo (REVAH, 1994). A respeito das semelhanças e diferenças entre essas experiências que se desenrolaram no Brasil e na Argentina, veja-se Revah (2015).
} 
A compreensão da mudança que ocorre nos docentes nesse período, por parte de García e outros profissionais da educação, resulta numa certa inversão, pois supõem que a partir da difusão da obra piagetiana e daquela investigação de Ferreiro e Teberosky e da assunção de seus corolários foi possível às "maestras" mudar como pessoas. Entretanto, essa mudança já vinha ocorrendo ligada a transformações culturais que foram as que na verdade alavancaram e deram sustentação à emergência do construtivismo. ${ }^{42}$ Nessas mudanças, além disso, encontra-se implicada uma importante via de aproximação à criança, pois o que a revista incentiva, sugere ou coloca nas entrelinhas, em artigos que podem ser encontrados em diferentes edições e momentos, é que os adultos desenvolvam em si próprios certos traços atribuídos à criança, como certo viés lúdico, a criatividade que eles teriam perdido, o prazer quando trabalham, à semelhança do envolvimento que a criança supostamente tem quando brinca, sendo assim aproximados jogo e trabalho. O que em tudo isso parece estar em pauta é a produção de uma nova sensibilidade nos docentes e também nos pais que implica o corpo, a expressão, o modo de falar e se dirigir às crianças, de se relacionar com elas, não mais no registro de uma moral avaliada como tradicional e ultrapassada, conforme um percurso que ademais envolve a emergência de determinados temas na revista, como educação sexual e expressão corporal. Tudo isso, enfim, supõe uma mudança no adulto num sentido amplo, global, que envolve a pessoa como um todo e que em parte toma a criança como guia e modelo do próprio adulto, como já era antecipado em discursos escolanovistas. Uma inversão histórica de importantes consequências, com a sua particular deriva quando esse guia fica no registro da psicologia e dos novos especialistas que emergem na década de 1980.

\section{Considerações finais}

As transformações que podem ser observadas nas representações sobre os docentes e a docência na revista La Obra fazem parte do longo processo que corrói a cultura do normalismo na Argentina, notadamente nas décadas aqui consideradas. Nesse processo, reconfigura-se a cultura docente dos níveis iniciais e assim são também criados os alicerces que deverão alavancar e sustentar a emergência de um novo discurso pedagógico na segunda metade da década de 1980, como se observa não apenas na Argentina, mas também no Brasil e noutros países no momento em que os discursos pedagógicos começam a ser (re)ordenados pelo significante construtivismo. Essa emergência, atribuída em geral à presença das conceitualizações piagetianas no campo pedagógico, com a sua particular incidência na alfabetização em razão dos desdobramentos didáticos das pesquisas sobre a psicogênese da língua escrita de Ferreiro e Teberosky (1986), sustenta-se em grande parte nas mudanças que vinham se desenrolando na cultura docente e que extrapolam o estreito marco da obra piagetiana e daquelas pesquisas.

Nessas mudanças, a imprensa educacional teve um papel importante, a começar pelo fato de ter colocado os docentes no centro da cena educativa e de ter-lhes proposto, enquanto leitores, uma questão fundamental: "el cambio de la escuela", como observa Finocchio sobre o papel da imprensa na segunda metade do século XX (2009, p. 133). No período aqui destacado, vimos primeiramente a centralidade dada aos docentes na imprensa oficial relacionada com a relevância a eles atribuída na Reforma Educativa impulsada pelo governo de Onganía. Os docentes são elogiados mas também criticados, assim como a escola e o sistema educativo, com um discurso modernizador e tecnocrático que atinge sobretudo os docentes da escola pública. Esses discursos oficiais constróem uma representação dos docentes como resistentes à mudança, numa escola que se considera envelhecida, num sistema educativo burocratizado e obsoleto. Nessa investida estão em causa aspectos da cultura docente então hegemônica, implicando portanto o normalismo, nesse período atingido também em razão da extinção das escolas normais e das críticas a elas endereçadas.

\footnotetext{
${ }^{42}$ Processo semelhante nota-se no Brasil (REVAH, 2004).
} 
Diferentes são as representações veiculadas na revista $L a$ Obra, a qual se mostra preocupada com o fechamento das escolas normais e recusa certas críticas feitas ao normalismo, reconhecendo porém a necessidade de mudanças. Diante da Reforma Educativa, sobressai seu posicionamento crítico, bem enfático em relação ao discurso tecnocrático. A sua posição também é clara na defesa dos docentes em face dos discursos que os desvalorizam, contrastando a sua situação com a época na qual o magistério gozava de certo prestígio. Se nesse período surge uma forma de resistência docente organizada é precisamente a das novas entidades de classe, com a unificação que resulta de suas ações e que a revista La Obra celebra, dando lugar a uma representação dos docentes que enaltece o professor que participa das lutas sindicais, por seus direitos, pela melhoria de suas condições de trabalho e das escolas, das públicas principalmente, numa sociedade e num sistema educativo que a revista critica porque julga que neles prima a desigualdade, com setores sociais e circuitos educativos privilegiados. São duas Argentinas. Mas a educação não deve ser um privilégio, é necessário promover a igualdade de oportunidades, destaca a revista La Obra logo após o fim dos governos ditatoriais da autoproclamada "Revolución Argentina", em 1973, assim mantendose em sintonia com os questionamentos que se ampliam desde fins da década de 1960 com a mobilização de diferentes setores sociais. Quando ocorre o golpe civil-militar de 1976, a revista mantém ainda tímidos questionamentos, até encerrar as suas edições nesse mesmo ano.

Temos aí então diferentes elementos presentes na revista La Obra que vão incidir na reconfiguração da cultura docente nesse período, que se estende do fim dos anos 1960 até 1976, e aos quais é preciso acrescentar a representação do docente como profissional, antes do que trabalhador, este um significante que a revista não usa em seus editoriais. Nesse ponto também é preciso incluir a recusa, por parte da revista, da docência como apostolado e dos apelos à maternidade, inerentes a figuras docentes que - tudo indica - sofrem crescente desgaste nesses anos de forma concomitante à valorização do docente que levanta a sua voz, que luta por seus direitos e participa nas greves que ocorrem no período.

Quando a revista La Obra é reiniciada, em 1978, logo é possível notar a circunscrição da ação do professor ao que acontece na sala de aula, às experiências que desenvolve com seus alunos, com uma forte demanda em relação ao domínio de determinadas concepções teóricas, em especial a teoria psicogenética piagetiana, e a exigência de relacionar estreitamente teoria e prática. Recusam-se as receitas e na revista destacam-se os relatos de docentes sobre as atividades que realizam com seus alunos, contrastando nesse ponto com os artigos da mesma revista da etapa anterior, nos quais predominava o viés prescritivo. Nota-se então a forte presença de docentes de escolas privadas consideradas progressistas, as quais de certo modo encontravam-se numa situação privilegiada para realizar suas experiências pedagógicas, se a compararmos com a situação das escolas públicas, pois, como assinala Andrade (2016, p. 98), elas contavam com "ciertos márgenes de libertad" inexistente na rede pública.

$\mathrm{Na}$ análise aqui desenvolvida sobre esse período foi ainda destacada a ampliação do campo da psicologia, com a inclusão de outras vertentes teóricas além da piagetiana, mas também a relevância de reflexões no campo da didática vinculadas a determinadas áreas do ensino. Nesse ponto foram distinguidos certos aspectos relacionados com a organização da revista e a sua forma material, como o destaque dado a determinados temas nas capas da publicação relacionados com a configuração do campo das didáticas especiais. Em relação às concepções piagetianas, foi também observada a sua presença na etapa anterior, sendo destacada inclusive a sua incidência na organização da revista, que em 1974 cria a seção "Piaget para maestros".

$\mathrm{Na}$ inflexão que é própria dessa etapa, quando a Argentina vivia sob o terrorismo de Estado, desaparecem da revista os questionamentos às políticas governamentais e tampouco se alude ao docente que luta por seus direitos. Prevalece então uma representação dos docentes vinculada à sua atuação dentro dos limites da sala de aula, mas mesmo assim há lugar para o surgimento de determinados temas ligados à renovação cultural que se processava nessas décadas, 
assim como para docentes que apresentam comportamentos, atitudes, posturas e formas de atuação que dizem respeito a essa renovação e que mais tarde, na segunda metade dos anos 1980, ficam sob a órbita do construtivismo, como se deste procedesse tudo o que seria essencial na forma de pensar e atuar dos docentes identificados com esse novo discurso pedagógico.

Em relação à nova etapa que se abre com o retorno da ordem constitucional, em 1983, foi destacada a articulação entre educação e democracia, assim como a relevância da dimensão política nas representações que a revista veicula sobre os docentes. Estes são incitados a olhar para além da sala de aula, das famílias e da escola. A comunidade surge então como uma realidade fundamental para a atuação do professor. Em torno dela, desse significante, ordena-se uma parte significativa dos discursos presentes na revista em meados dessa década, incidindo inclusive na sua organização e no que é destacado em suas capas. Nessa etapa surge a figura do docente militante empenhado na criação de uma nova forma de vida, uma vida democrática, atento não apenas às questões de ordem pedagógica, mas também às institucionais e sindicais. A consideração da escola enquanto instituição, a dimensão coletiva envolvida na docência e o cooperativismo são também aspectos importantes nessas representações que, no período, reconfiguram a maneira de situar a docência nas páginas da revista. Uma reconfiguração que será em boa medida pautada pela lembrança do passado recente, a lembrança da violência política e das atrocidades cometidas pela ditadura. Daí a ênfase na democracia e na liberdade, a referência ao autoritarismo e a necessidade de formar sujeitos críticos e voltados para a transformação da sociedade, assim como o incentivo a uma militância docente que seja pacífica, que se desenrole num campo de luta voltado para a paz. Na revista, a democracia é debate e conflito, mas também supõe a busca de unidade e harmonia, segundo argumentam diferentes autores.

Por último, no final deste artigo foi destacado o que tende a se afirmar cada vez mais na década de 1980: o questionamento dos docentes, da sua formação e atuação, que também atinge a escola enquanto instituição, em particular a pública, numa deriva já assinalada por Garaban (2009) e que podemos supor afetou também a representação dos professores das escolas públicas, crescentemente desprestigiada. Na revista La Obra, após a etapa que corresponde à vigência do regime militar, com uma presença acentuada de instituições do ensino privado, não é possível dizer que seu percurso corresponda ao dessa deriva. Nos já referidos artigos de Guillermo García, percebe-se inclusive que a prioridade é mostrar experiências didáticas avaliadas favoravelmente que são desenvolvidas por "maestras" de escolas públicas. Nesse percurso, que já adentra na segunda metade dos anos 1980, nota-se que a representação dicotômica dos docentes aos quais se alude na década anterior e ainda na seguinte - muito elogiados e ao mesmo tempo reduzidos a quase nada porque desvalorizados - tende a desaparecer, sobressaindo cada vez mais o questionamento da formação dos docentes e da sua atuação. E o que nessa trajetória afinal emerge é o perfil docente que supostamente vem preencher o vazio que na revista provavelmente operava impulsando o esforço pela definição de um novo modelo didático, uma nova pedagogia, uma pedagogia construtivista, como se vê nos artigos de García. Essa representação do professor dentro do marco definidos pelo construtivismo, junto com tudo o que esse discurso incorpora e transforma de representações e discursos anteriores, tornar-se-á uma parte importante do que deverá entrar no registro da reforma educativa empreendida na Argentina na década de 1990. Ademais, sob esse novo marco, a dimensão política e militante que na revista havia adquirido certa relevância logo após o fim da última ditadura tende a se esvair, não definindo mais o norte da ação docente. O novo guia ou modelo (re)surge então no centro da trama onde as questões didáticas são pensadas a partir dos discursos "psi”. Em outras palavras, o norte agora tende a ser dado pela "criança" que esses discursos recortam e na qual o docente (re)encontra o espelho onde pode avistar o que deve ser e fazer. 


\section{REFERÊNCIAS}

ANDRADE, G. B. (2016). Innovación pedagógica en tiempos de dictadura. Alcances, posibilidades y limitaciones (Tesis de maestría). Universidad Nacional de Luján, Argentina.

BALDUZZI, J., VÁZQUEZ, S. A. De apóstoles a trabajadores. Luchas por la unidad sindical docente. 1957 - 1973. Buenos Aires: Instituto de Investigaciones Pedagógicas Marina Vilte, Confederación de Trabajadores de la Educación de la República Argentina, 2000. https://doi.org/10.17227/01224328.4317

CARUSO, M., FAIRSTEIN, G. Las puertas del cielo. Hipótesis acerca de la recepción de la psicogénesis y el constructivismo de raíz piagetiana en el campo pedagógico (1950-1981). In: PUIGGRÓS, A. (dirección.). Historia de la Educación en la Argentina VIII: dictaduras y utopías en la historia reciente de la educación argentina (1955-1983). Buenos Aires: Galerna, 2003. https://doi.org/10.25145/c.educomp.2018.16.018

CARvalHO, M. M. C. Livros e revistas para professores. Configuração material do impresso e circulação internacional de modelos pedagógicos. In: PINTASSILGO, J., FREITAS, M. C. de, MOGARRO, M. J., CARVALHO, M. M. C. (org.). História da Escola em Portugal e no Brasil. Circulação e apropriação de modelos culturais. Lisboa: Colibri, 2006. https://doi.org/10.7213/dialogo.educ.15.046.ds07

CHARTIER, R. O mundo como representação. In: Estudos Avançados, v. 5, nº 11. São Paulo: IEA/USP, 1991. https://doi.org/10.1590/s0103-40141991000100010

DAVINI, M. C. La formación docente em cuestión: política y pedagogía. Buenos Aires: Paidós, 2010.

FERREIRO, E., TEBEROSKY, A. Psicogênese da lingua escrita. Porto Alegre: Artes Médicas, 1986.

FINOCCHIO, S. La escuela en la Historia Argentina. Buenos Aires: Edhasa, 2009. https://doi.org/10.18294/pm.2009.491

GARABAN, A. M. M. Lo público de la educación pública: la reforma educativa de los noventa en Argentina. México: 2009. https://doi.org/10.17141/iconos.35.2009.1311

NÓVOA, A. A imprensa de Educação e Ensino. In: CATANI, D. B., BASTOS, M. H. C. (org.). Educação em Revista - A imprensa periódica e a história da educação. São Paulo: Escrituras, 1997. https://doi.org/10.4025/rbhe.v19.2019.e058

PINEAU, P. Impactos de um asueto educacional. Las políticas educativas de la dictadura (1976-1983). In: PINEAU, P.; MARIÑO, M.; ARATA, N.; MERCADO, B. El principio del fin.Políticas y memórias de la educación en la última dictadura militar (1976-1983). Buenos Aires: Colihue, 2006. https://doi.org/10.1590/s0104-40602014000100018 
PUIGGRÓS, A. Espiritualismo, Normalismo y Educación. In: PUIGGRÓS, A. (dirección.). Historia de la Educación en la Argentina VIII: dictaduras y utopías en la historia reciente de la educación argentina (1955-1983). Buenos Aires: Galerna, 2003. https://doi.org/10.25145/c.educomp.2018.16.018

REVAH, D. (2015). Trajetórias em sintonia: "Escolas alternativas" (São Paulo) e "Escuelas progresistas" (Buenos Aires) nas tramas da mudança cultural e dos regimes políticos das últimas décadas (1960-1990). $5^{\circ}$ Congreso Nacional e Internacional de Estudios Comparados en Educación. Educación y Futuro. Debates y desafios em perspectiva internacional. Disponível em: http://www.saece.org.ar/docs/congreso5/trab105.pdf. https://doi.org/10.11606/t.102.2019.tde-26042019-125327

Construtivismo: uma palavra no circuito do desejo. Tese de Doutorado, Faculdade de Educação/USP, São Paulo, 2004. https://doi.org/10.11606/t.48.2004.tde-06092011-124739

. Na trilha da palavra "alternativa": a mudança cultural e as pré-escolas "alternativas". Universidade de São Paulo, Faculdade de Filosofia, Letras e Ciências Humanas. Dissertação de Mestrado, 1994. https://doi.org/10.11606/d.8.2007.tde-03032008-140341

SAVIANI, Dermeval. Escola e Democracia. São Paulo: Cortez, 1984.

SIEDE, I. A. (1995). Las escuelas progresistas laicas en la educación privada de Capital Federal entre 1955 y 1983. Seminario de doctorado. Universidad de Buenos Aires. Facultad de Filosofía y Letras, 1995. https://doi.org/10.2307/2267473

SOUTHWELL, M. Algunas características de la formación docente en la historia educativa reciente. El legado del espiritualismo y el tecnocratismo (1955-76). In: PUIGGRÓS, A. (dirección.). Historia de la Educación en la Argentina VIII: dictaduras y utopías en la historia reciente de la educación argentina (1955-1983). Buenos Aires: Galerna, 2003. https://doi.org/10.14409/cya.v0i18/19.4754

Una aproximación al proyecto educacional de la Argentina post-dictatorial: el fin de algunos imaginarios. Cuaderno de Pedagogía, año V, nº 10. Rosario: Laborde, 2002.

SUASNÁBAR, C. Intelectuales, exilios y educación. Producción intelectual e innovaciones en educación durante la última dictadura. Rosario: Prohistoria, 2013.

WEINSTEIN, I. (2007). La demanda de educación progresista. Evolución del discurso en las escuelas privadas progresistas. (Buenos Aires, 1970 - 2000). Tesis de Maestría en Educación. Universidad de San Andrés. Buenos Aires. Argentina. https://doi.org/10.25145/c.educomp.2018.16.018 